\title{
A balkáni nők jogi helyzete a 19. századtól napjainkig
}

\author{
Legal Status of Women in the Balkans from the $19^{\text {th }}$ Century to the Present
}

\begin{abstract}
ABSZTRAKT
Az egyik legfontosabb szerb jogalkotási eredmény az 1844. évi szerb Polgári Törvénykönyv, amely több mint száz évig maradt hatályban. Keletkezése arra az időszakra nyúlik vissza, amikor az ország még az Oszmán Birodalom része volt. Létrehozásának pillanatától komoly bírálatok érték, hiszen az osztrák Ptk. átvételéről van szó, amely nem felelt meg a szerb jogi-társadalmi viszonyoknak, ezért semmi nem valószínüsítette, hogy tartósan hatályban maradhat. Mégis túlélte a Szerb Fejedelemség, a Szerb Királyság, a Szerb-Horvát-Szlovén Királyság és a Jugoszláv Királyság államjogi rendszerét is, mielőtt a szocialista Jugoszlávia felszámolta 1945-ben.

Százéves története során a legtöbb bírálat a nőket érintő diszkriminatív rendelkezéseire irányult. Föként a férjes asszonyok jogi helyzete volt hátrányos, mivel cselekvőképességgel sem bírtak, férjük képviselte őket. Az egyenjogúság kimondására 1946-ban került sor, de ténylegesen csak a 20. század végén vívtak ki a férfiakkal azonos jogi státuszt.
\end{abstract}

Kulcsszavak: az 1844. évi szerb Polgári Törvénykönyv, Optk., zadruga, a nők jogai és kötelességei, a nők emancipációja

\begin{abstract}
One of the most important pieces of legislations in Serbian history was the Serbian Civil Code of 1844, which remained in force for more than 100 years. It dates back to the time when the country was still part of the Ottoman Empire. From the moment it was created, there has been serious criticism, like this is a takeover of the Austrian civil code, which does not correspond to Serbian legal-social relations, so there was no indication that it would be a durable legislation. It has survived the state law regimes of the Principality of Serbia, the Kingdom of Serbia, the Kingdom of Serbs-Croats and Slovenians and the Kingdom of Yugoslavia before being liquidated by socialist Yugoslavia in 1945.

In its 100-year history, most of the criticism concerned the discriminatory provisions on women. Mostly, the legal situation of married women was detrimental, as they had no capacity to act, and were represented by their husbands. Their proclaimed equality took place in 1946, but they actually received the same legal status as men in the late $20^{\text {th }}$ century.
\end{abstract}

Keywords: Serbian Civil Code of 1844, Civil Code of Austria (1811), zadruga, rights and duties of women, women's emancipation

A szerb jogalkotás egyik legfontosabb terméke az 1844. évi szerb Polgári Törvénykönyv, amely több mint száz évig maradt hatályban. Keletkezése arra az időszakra nyúlik vissza, amikor az ország még az Oszmán Birodalom része volt. Létrehozá-

\footnotetext{
* Dr. Heka László, egyetemi docens, Szegedi Tudományegyetem Állam- és Jogtudományi Kar, Összehasonlító Jogi és Jogelméleti Intézet, e-mail: heka@juris.u-szeged.hu.
} 
sának pillanatától komoly bírálatok érték, hiszen az Osztrák Polgári Törvénykönyv (Allgemeines bürgerliches Gesetzbuch für die gesamten deutschen Erbländer der Österreichischen Monarchie, $A B G B, 1811)$ átvételéröl volt szó, amely nem felelt meg a szerb jogi és társadalmi viszonyoknak. Ezért semmi nem utalt arra, hogy tartósan hatályban fog maradni. Mégis túlélte a Szerb Fejedelemség, a Szerb Királyság, a Szerb-Horvát-Szlovén Királyság és a Jugoszláv Királyság államjogi rendszerét, mielőtt a szocialista Jugoszlávia felszámolta 1945-ben.

A nőkre vonatkozó diszkriminatív rendelkezései, és föként a férjes asszonyok jogi helyzetének szabályozása miatt retrográd törvény hírében állt. Ennek ellenére mégis nagy befolyással bírt a délszláv térségbeli nők jogállására, hátrányos helyzetére. Az egyenjogúság kimondására 1946-ban sor került ugyan, de a nők ténylegesen csak a 20. század végén vívták ki a férfiakkal azonos jogi státuszt.

\section{A szerb Ptk. megalkotásának előzményei}

A szerb Ptk. kidolgozását Miloš Obrenović (1780-1860) fejedelem tủzte ki célul. Ő maga paraszti családból származott, írástudatlan volt, de uralkodása alatt nagy figyelmet fordított az oktatásra és önállósodni kívánó országa jogi alapjainak lefektetésére. Az elmaradott Szerbiának a pravoszláv papságon és katonatiszteken kívül nem volt értelmisége, ezért többnyire az Osztrák-Magyar Monarchia területén élő szerb tanítókra, ügyvédekre, orvosokra támaszkodott, akik nagy szimpátiával üdvözölték az Oszmán Birodalomtól függetlenedni kívánó ország törekvéseit. ${ }^{1}$

Miloš fejedelem az általa kijelölt úton haladva a francia és az osztrák mintát kívánta követni. Ezért megbízta a nyelvészeit az 1804. évi francia Code civil (Cc.) és az 1811. évi Osztrák Polgári Törvénykönyv lefordításával, azzal a szándékkal, hogy e két törvény alapján alkossanak meg egy, a szerb viszonyoknak megfelelö Ptk.-t. A Code civil lefordítását Vuk Stefanović Karadžić nyelvújítóra bízta 1829-ben, akinek

${ }^{1}$ A szerbek megkülönböztették a Monarchiából áttelepült honfitársaikat, akiket nemačkari-nak (németesek) neveztek el. Az állami támogatással nyugati (föként francia) egyetemeken tanult értelmiségiek is elismerésben részesültek, úgy nevezett „béleget” kaptak. Öket parizlije (párizsiak) névvel illették. RADENIć, Andrija: Spoljna politika Srbije u kontroverznoj istoriografiji: od Načertanija 1844. do stvaranja Jugoslavije 1914-1918. Službeni glasnik, Beograd, 2006, 90, 158.; BATAKović, Dušan T.: French Influence in Serbia 1835-1914. Four Generations of "Parisians." Balcanica, 2005, 93-129. (DOI:10.2298/BALC1041093B) http://www.balcanica.rs/ balcanica/uploaded/balcanica/balcanica\%2041/05\%20DtB\%20PArizlije.pdf (2020. 08. 23.); BEŠLIN, Branko: Srpski liberalizam u XIX veku. Zbornik Matice srpske za istoriju, 2003, 59-104.; JovANOvić, Slobodan: Vlada Aleksandra Obrenovića I-II. BIGZ, Beograd, 1990.; TRGovćEVIĆ-MITRovIĆ, L. M.: Srpska inteligencija u XIX veku - zapadni i istočni uticaji. Zbornik radova - Evropa i Srbi, 1996, 261-273.; JovANović, Slobodan: „Nemačkari.” In: Sabrana dela Sabrana dela Slobodana Jovanovića. BIGZ, Beograd, 1991.; KASER, Karl: Typologie der politischen Parteien Südosteuropas im neunzehnten Jahrhundert. Österreichische Osthefte, 1985, 331-365; KRESTIĆ, Petar V.: Political and Social Rivalries in Nineteenth-century Serbia. Švabe or Nemačkari. Balcanica, 2005, 73-92.; MITROVIć, Ljubiša-ĐoRĐEVIć, Dragoljub-Todorović, Dragan: Civilno društvo i multikulturalizam na Balkanu. (Zbornik diskusija sa okruglih stolova). Niš, 2004, 67. https://npao. ni.ac.rs/files/584/08_Zbornik_Civilno_drustvo_i_multikulturalizam_na_Balkanu_10dc7.pdf (2020.08. 23.).; Pavlović, Vojislav: Srpski studenti u Parizu 1839-1856., I. Istorijski časopis, 1987, 188-199.; TATIć, Uroš: Srpski pitomci na školovanju u Parizu šezdesetih godina XIX veka. Kultura, 2019, br. 164, 99-126. (DOI: 10.5937/kultura1964099T); Žusović, Jovan: L'influence intellectuelle française sur la Serbie. Vannes, 1918. 
a számára a feladat túl nehéznek bizonyult, tekintettel arra, hogy autodidakta módon képezte magát. ${ }^{2} \mathrm{~A}$ napóleoni törvénykönyv terminológiája nagy problémát okozott a fejedelem többi fordítója számára is, mivel az ötszáz évig elszigetelt török tartományban nem ismerték a korabeli francia jogi szakkifejezéseket, például a servitut kifejezést sem. Korábbi ismereteikből a rabszolgaság elnevezésének vélték, logikáját tekintve azonban az egyáltalán nem illett bele a szövegkörnyezetbe. Végül egy jogban jártas, lengyel férfi fejtette meg a „titkot.” Megrökönyödve kérdezte: „Önök ilyen fogalmakat nem ismernek, ennek ellenére polgári törvénykönyvet akarnak alkotni?"3 Más római jogi eredetű, latin jogi fogalommal is megesett a bajuk. A jelzálogot (hypotheca) elírásnak tartották, amely szerintük a gyógyszertár (apotheka) szó helyett "tévesen” szerepel a Code civilben. ${ }^{4}$ Amikor a fejedelem belátta, hogy „szakértői” alkalmatlanok a törvénykönyv feldolgozására, lemondott annak átvételéről. Erre bíztatta őt a szerb színház alapítója, a bajai születésű Joakim Vujić (egyben a magyarországi szerb színjátszás kezdeményezője is), aki 1833. május 20-án írt levelében jelezte Milos hercegnek, hogy a Code civil fordítása értelmetlen, és nem használható fel. ${ }^{5}$ Szembesülve a nehézségekkel a fejedelem és a törvényhozó bizottság 1837-ben Hadzsics János (Jovan Hadžić) újvidéki szenátort és ügyvédet bízta meg a szerb polgári törvénykönyv megalkotásával. ${ }^{6} \mathrm{~A}$ szerb kormánnyal 1840 . július 29-én kötött szerződés értelmében Hadžić vállalta, hogy két éven belül kidolgozza a kódexet. Ezután visszatért Magyarországra (a szerb szerzők Ausztriának nevezik az államot, Újvidéket is annak részeként) és folytatta a munkáját az újvidéki magisztrátusban és a gimnáziumban. ${ }^{7}$ Mivel napi szinten alkalmazta az Optk.-t, nem

2 Jovanović, Aleksa S.: Rad na „toržestvenim zakonima.” Arhiv za pravne i društvene nauke 8, Beograd, $1909,17$.

${ }_{3}^{3}$ Avramović, Sima: Srpski građanski zakonik 1844. i pravni transplanti. In: Srpski građanski zakonik 170. godina. Beograd, 2014, 21. http://www.ius.bg.ac.rs/drakitic/Srpski-gradjanski-zakonik_170-godina.pdf (2020. 08. 23.).

${ }^{4}$ Nikolıć, Dragan: Rad na građanskom zakoniku u Srbiji 1829-1835. godine. In: Jovičić, Miodrag (szerk.): Sto pedeset godina od donošenja Srpskog građanskog zakonika (1844-1994), Beograd, 1996, 89.; KRKLJUŠ, Ljubomirka: Donošenje Zakonika građanskog za Kneževinu Srbiju. Glasnik Advokatske komore Vojvodine, 1994/6, 5.; NıKolıć Dušan: Dva veka građanskog prava u obnovljenoj Srbiji. Glasnik Advokatske komore Vojvodine, 2004/4, 157-158.

${ }^{5}$ Nikolıć, Dragan: Građanski zakonik. Knez Miloš Obrenović i Zakonodavna komisija u Srbiji 1829-1835. godine. In: Srpski građanski zakonik 170. godina. Beograd, 2014, 63-74.

${ }^{6}$ Hadzsics János Zomborban született, majd Kalocsán végezte a gimnáziumot. Bölcsészetet és jogot a pesti egyetemen tanult. A kormány kinevezte a végvidék ügyészévé, ezután 1830-ban a bácsi szentszék ügyésze és az újvidéki gimnázium igazgatója lett. 1834-ben Újvidék városi tanácsossá volt, majd 1837-ben Milos fejedelem megbízásából készítette el a Ptk.-t. Ezután ismét visszatért Magyarországra, és 1847-ben Újvidék országgyűlési követte volt. 1850-ben a délmagyarországi bíróságok szervezését kapta feladatul, végül az újvidéki kerületi bíróság elnökeként vonult nyugdíjba 1854-ben. SzINNYEI József: Magyar írók élete és munkái IV. Budapest, 1896, 233-235.

7 Čorović, Vladimir: Istorija Jugoslavije. Narodno delo, Beograd, 1933; Nıkolıć, Dušan: Uticaj istaknutih pravnika na oblikovanje prava u Evropi i Srbiji. Zbornik radova Pravnog fakulteta, 2010/3, 183-201., 187, $188,189$. http://zbornik.pf.uns.ac.rs/images/download/2010/2010-3/doi_10.5937_zrpfns44-0050.pdf (2020. 08. 23.); STANKOVIĆ, Uroš: Hiljadu osamsto četrdeset šesta - Naslednopravni položaj ženske dece nom redu po trećinom redu. In: Srpski građanski zakonik 170. godina. Beograd, 2014, 407-416., 408.; Krestić, Petar V.: Kad će Srbin Srbina Srbinom zvati. Srpsko nasledje, Novembar 1998. http://www.srpsko-nasledje.rs/sr-1/1998/11/ article-10.html (2020. 08. 23.); MILosAVLJEVIć, Olivera: U tradiciji nacionalizma ili stereotipi srpskih intelektualaca XX veka o „nama” i „drugima.” Helsinški odbor za ljudska prava u Srbij, Beograd, 2002.; „Dimitrije Davidović az 1835. évi alkotmány (Sretenjski ustav) és Jovan Hadžić, az első szerb polgári törvénykönyv (1844) 
meglepő, hogy azt vette alapul. Az újvidéki ügyvéd egy fejlett, nyugati típusú államban élt, így a jogról való felfogása természetesen más volt, mint az oszmán állam keretein belül élő honfitársainak, akiknek a politikai, jogi, kulturális felemelkedésre öt évszázadon keresztül nem volt lehetőségük. Ezért az ott élő lakosság az ekként elkészült szerb Ptk.-val nem tudott azonosulni.

\section{A törvénykönyv kritikája}

Az 1844. március 25-én elfogadott Szerb Fejedelemségi Polgári Törvénykönyv (Zakonik građanskij za Knjaževstvo Srbiju, Законик Грађанскиј за Књажевство Србију) fogadtatása kifejezetten negatív volt. Az első és leghevesebb kritikusa a karlócai születésü, egykori szegedi piarista diák, Pavle Šeroglić (Seroglics Pál) volt, aki leginkább azzal vádolta Hadžićot, hogy nemcsak egyes cikkelyeket „vett át” az Optk.-ból, hanem olykor egész fejezeteket is, kivéve a nők jogaira vonatkozó rendelkezéseket. ${ }^{8}$ Véleménye szerint „még a Koránban is kedvezőbb a nők öröklési jogosultsága, mint a szerb Ptk.-ban.”9 Kritikák lavinája zúdult a 950 cikkelyből álló szerb Ptk.-ra, amelyet „az Optk. rövidített változatának” (az ABGB-nek 1502 cikkelye volt), „másolatának”, „rossz fordításának”, „kompilációjának” neveztek a szerb és jugoszláv jugtudósok, hangoztatva, hogy „semmi köze sincs a szerbiai viszonyokhoz”, és a szerb ember számára „teljesen idegen szabályozást tartalmaz”. ${ }^{10}$ A törvénykönyv alkotójának szemére hányták azt is, hogy nem ismeri és „nem érti” a helyi viszonyokat, mivel a határon túl él. ${ }^{11}$ Felrótták továbbá, hogy „német”, a bécsi érdekek képviselője, aki munkájáért nagy bevételt kap (1844-ben valóban nagy összeget, háromezer tallért ajánlottak neki kétéves szerződéssel), valamint megvádolták még a szerb társadalom egyik fontos intézményének, a zadrugának (azaz házközösségnek) a „szétrombolásával” is. Öt hibáztatták többek között a nép elszegényesedéséért, a szerb gazdaság gyengüléséért.

A szerb törvénykönyvet a régió talán legtekintélyesebb 19. századi jogtudósa, Baltazar (Valtazar) Bogišić is bírálta. Leginkább annak családi és öröklési rendelke-

alkotója Ausztriában született és képezte magát. Az 1842. és 1858. közötti időben az ún. 'alkotmányvédők' kormányzása alatt - Karagyorgyevics Sándor hercegsége alatt -, az ausztriai szerbek foglalták el a legfontosabb pozíciókat. Ök voltak az uralkodó tanácsadói, írnokai, mind a négy minisztérium élén ők álltak, a tisztviselök, a tanult papság, a tanítók, tanárok és orvosok java része közülük került ki." Lajdinger, Hanes: Srbija-Austrija - Aspekti bilateralnih odnosa od 1836. do 1914. Beleške burnih odnosa. Vreme, 2014. 09. 11. https://www.vreme.com/cms/view.php?id=1227359 (2020. 08. 23.).

${ }^{8}$ Seroglics Pál Szegeden 1819-től 1821-ig tanult bölcsészetet, annak elvégzése után Sárospatakon és Pesten folytatta jogi tanulmányait. Ügyvédi karrierjét Pesten kezdte. DRAKIĆ, Gordana M.-STANKović, Uroš: Život i delo Pavla Šeroglića (1800-1857). Zbornik Pravnog fakulteta u Novom Sadu, 2016, 1215-1216.

9 ŠERgolić, Pavle: Pregled Zakonika Građanskog za Knjaževstvo Serbiju 25. marta obnarodovanog. Bačka Vila 4/1845, Novi Sad, 1845, 114-187., 138.; MAtıć, Dimitrije: Objasnenija Gradjanskog zakonika za Knjaževstvo Srpsko, I-III. Beograd, 1850-51, 540-543.; AvRAmović: i. m., 17.

10 ĐorĐević, Miroslav: Pravni transplanti i Srbijanski građanski zakonik iz 1844. Beograd, 2006, 6.

${ }^{11}$ Az újvidéki ügyvéd nem volt népszerü, mivel ellenezte Vuk Karadžić akkori nyelvi reformját, amelynek célja a hercegovinai lakosság nyelvjárásának hivatalossá tétele volt, az addigi szerb nyelv helyet. 
zéseit kritizálta, amiért azok „idegen mintára” készültek el. ${ }^{12} \mathrm{Az}$ általa kidolgozott és 1888. július 1-jén hatályba lépett Montenegrói általános vagyonjogi törvény (Opšti imovinski zakonik za knjaževinu Crnu Goru) ugyanis a szokásjogra épült. Ez a polgári jogi kódex újdonság volt a szlávság körében és nagy sikert aratott. Megjelenését követően a szerb jogászok arra törekedtek, hogy meglévő Ptk.jukat hatályon kívül helyeztessék, és egy újat alkossanak a montenegrói törvény példájára. Azonban erre végül nem került sor, sőt még a meglévő törvény átfogó módosítására sem. Kísérletek voltak: 1862-ben, 1864-ben és 1872-ben történtek (kisebb) módosítások. Ezután az Igazságügyi Minisztérium 1908-ban kinevezett egy bizottságot azzal a feladattal, hogy új törvényt alkosson a montenegrói polgári törvénykönyv mintájára. Az 1911-ben elkészült módosítások azonban csupán a végrendeletet érintették. A két balkáni háború, az első világháború, majd az új állam (Szerb-Horvát-Szlovén Királyság) keletkezése miatt elhalasztották az új Ptk. kidolgozását. Habár a jogi partikularizmus komoly gondot okozott a királyságban, a délszláv államon belüli nemzetiségi feszültségek nem tették lehetővé a magánjog egységesítését. Az 1929. január 6-án bevezetett királydiktatúrát követően Karagyorgyevics Sándor 1930-ban újabb kodifikációs bizottságot nevezett ki, amely 1934-ben megjelentette a Ptk. vázlatát. Ez további polémiákat indított el. A szerb-montenegrói országrész (beleértve a későbbi Macedóniát és Koszovót) orosz-francia párti volt és a montenegrói törvény mellett állt ki. A német-osztrákbarát nyugati részek (Szlovénia és Horvátország) pedig ismét az osztrák modell követésére voksoltak. ${ }^{13}$ Megállapodás hiányában azonban a szerb Ptk. maradt hatályban egészen a szocialista Jugoszlávia megalakulásáig, amikor „az 1941. április 6. előtt hozott jogszabályok érvényességéről szóló törvény" végleg megszüntette annak hatályát. ${ }^{14}$

Ekként a Ptk. túlélte az 1878-ban függetlenné vált Szerb Fejedelemséget, majd 1882-töl a Szerb Királyságot, a Szerb-Horvát-Szlovén Királyságot (1918-tól), valamint a Jugoszláv Királyságot (1929-töl 1945-ig) is.

A szerb Ptk. értékelése ismét hangot kapott 1995-ben, amikor a törvény 150. évfordulójáról emlékeztek meg. Az erre az alkalomra készült kiadványokban (1995-ben és 1996-ban) azonban már más volt a hangnem. Ekkor érdemei közül kiemelték, hogy a hosszabb ideig hatályos európai polgári törvénykönyvek (kodifikációk) közül a szerb Ptk. a negyedik legrégebbi, és csak a francia Code civil (Cc, 1804), az Optk. (ABGB, 1812), illetve az 1838-ban létrejött holland Ptk. (Burgerlijk Wetboek) keletkeztek korábban. ${ }^{15}$ Kiálltak a nőkre vonatkozó szabályozások mellett is, mondván: „,nehéz lett volna a szerb Ptk.-ba beépíteni a szokásokkal és a domináns viselkedési normákkal ellentétes rendelkezéseket."16 Sima Avramović szerint Hadžić legalább

\footnotetext{
${ }^{12}$ Bogıšıć, Baltazar: Naputak za opisivanje pravnijeh običaja, koji u narodu živu. (Iz Književnika III.). Brzotisk Dragutina Albrechta, Zagreb, 1867; és Pravni običaji u Slovena I., Zagreb, 1867, 225-241.

${ }^{13}$ Nikolıć, Dušan: Dva veka građanskog prava u obnovljenoj Srbiji 1804-2004. Zbornik radova Pravnog fakulteta u Novom Sadu, 2004/2, 277-309.

${ }^{14}$ Pravno-informacioni sistem Republike Srbije. https://www.pravno-informacioni-sistem.rs/SIGlasnikPortal/eli/ rep/slfnrj/skupstina/zakon/1946/86/4/reg (2020. 08. 28.).

15 Megjegyzendő, hogy Bajorországnak is volt ilyen, korábbi kodifikációja, a Codex Maximilianeus Bavaricus Civilis (1756).

${ }^{16}$ Avramović: i. m., 17.
} 
annyi jogot szeretett volna biztosítani a nöknek, mint amennyivel Magyarországon rendelkeztek. Milos fejedelem és követői elutasították. Úgy vélték, túl korai lenne gyökeres váloztatásokat bevezetni a patriárhális szerb társadalomba. Megítélésük szerint a női jogok garantálása megváltoztatta volna a zadrugák rendszerét, amely sértette volna a "nemzeti büszkeségüket." A fejedelem és apparátusa 1837. december 17-én a „nép és a sztaresinák körében” lefolytatott egy vizsgálatot arra vonatkozóan, hogy bevezethető lenne-e a leánygyermekek hagyatékból való részesülése. Az erre kapott nemleges választ, vagyis a nöi öröklés kizárását 1842-ben a népgyülés is megerősítette.

A szerb polgári törvénykönyvet ért sok kritika ellenére elmondható, hogy Hadžić praktizáló ügyvédként a Ptk.-ba beépítette a római jogot (recepció utján, főként az ABGB egyes intézményeinek átvételével), érezhető benne a francia Cc. hatása, a pravoszláv egyházjog, a szerb szokásjog, sőt bizonyos kérdésekben a shari'a jog befolyása, illetve a Szerbiában több évszázadon át alkalmazott oszmán jog (egyes intézményeinek) hatása is. ${ }^{17}$ Munkájával megteremtette a szerb jogi terminológiát és a fejlődés útjára állította az öt évszázados oszmán uralom alatt stagnáló szerb jogot. ${ }^{18}$

Tehát Szerbia magánjoga fejlődésnek indult az Optk.-t követő kodifikációval, vagyis egy fejlett ország jogának egy sokkal elmaradottabb jogrendszerbe való átvételével. Esetében igaznak bizonyult Alan Watson tézise, amely szerint a jogfejlődés nem mindig magyarázható a Friedrich Karl von Savigny Volksgeist-jára és jogi evolúcióra való hivatkozással. ${ }^{19}$

\section{A házközösség (zadruga)}

A Dinári hegyvidéken (Dinaridi) a vérségi leszármazásra és közös vagyonra épülö házközösség (zadruga, nagycsalád) tulajdonképpen a honfoglalástól fennálló osztatlan vagyoni, termelési és fogyasztási közösség volt. Eleinte az egy fedél alatt élőkből állt, de a népesség növekedése során több - egymással vérrokonságban álló - család alkotta. Az egy telken élő nagyszülők, szülők, gyermekek, testvérek és menyek közösségeként szervezte meg a védelmet, kezelte a vagyont és fedezte a fenntartási költségeket. ${ }^{20} \mathrm{~A}$ közös földbirtok gyakran egy egész településre kiterjedt, majd további bővülések során jött létre a bratstvo (atyafiság, szó szerint: testvérség) vagy rod (szó szerint: rokonság). Több atyafiság közös őstöl származott (djed: nagy-

\footnotetext{
${ }^{17}$ KNEŽıć-PoPović, Dragana: Udeo izvornog rimskog prava u Srpskom građanskom zakoniku. In: Sto pedeset godina od donošenja Srpskog građanskog zakonika (1844-1994). Naučni skupovi SANU, knj. LXXXI, Odeljenje društvenih nauka, knj. 18, Beograd, 1996, 72. A shari'a jog befolyása a jogi terminológia terén is igazolható, föként a vagyonjogban. Legismertebbek a tapia (946. §), a miljak, (475§) a török milk intézmény alapján, az amanet (575. §), a kesim (693-694 §), a kirija (ingatlanok bérleti díja). Bővebben: BEGovıć, Mehmed: Uticaj šerijatskog prava na pravne običaje u Jugoslaviji. Godišnjak Pravnog fakulteta u Sarajevu, 22/1974, 375-381.

18 ŠARKIĆ, Srđan: Kalimahov kodeks - Malo poznata kodifikacija koja je prethodila Srpskom građanskom zakoniku. In: Srpski građanski zakonik 170. godina. Beograd, 2014, 48.

${ }^{19}$ Đorđević: i. m., 62-84.

${ }^{20}$ A Balkánon egy zadruga általában három-öt családot foglalt magában, a délszlávoknál a létszáma húszötven fö lehetett, az albánoknál pedig akár nyolcvan-száz fő közötti is).
} 
apa), a tulajdonuk elnevezése djedovina, amely akár több falura is kiterjedhetett. A házközösségben a férfiakat a közös vérvonal kötötte össze, a nők pedig házasság útján kerültek abba. A leánygyermekek, amíg nem mentek férjhez, szintén oda tartoztak, valamint azok az özvegyek is, akik férjük halála után visszatértek a szülöi házba. A szerb Ptk. 57. §-a szerint a zadruga „több felnőtt személy közössége, akik egyedül vagy utódaikkal együtt egy közösségben élnek. "A családok felnőtt férfi tagjai irányították a gazdálkodást, az egész házközösség élére pedig megválasztották a starešinát (sztaresina, pater familas), aki általában a legöregebb, legbölcsebb férfi volt. ${ }^{21}$

Amíg a balkáni zadrugák a szokásjog alapján működtek és a nőknek kevés jogot biztosítottak, addig Magyarországon és Horvátországban a Katonai határőrvidéki házközösségek jogállását több törvény vagy statútum rendezte. ${ }^{22}$ Azok előírták, hogy a nagycsalád tagjának számított minden férfi és nő, akik közül a felnőtt korúak (akiknek már nem éltek a felmenői) jogosultak voltak kérni a házközösség felosztását. ${ }^{23}$

A monarchiabeli zadrugákban az özvegy a gyerekeivel együtt az elhunyt férjének haszonélvezeti jogát örökölte, ha pedig a vagyon felosztására került volna sor, akkor rá és gyermekeire az Optk. rendelkezéseit alkalmazták. ${ }^{24}$ A gyermektelen özvegy haszonélvezeti joga azonos volt a többi családtagéval, emellett a vagyonfelosztás esetében jogosult volt tulajdonként örökölni az elhunyt házastársa részének egynegyedét (31. §). ${ }^{25}$ Férje halála után a feleség megkapta az összes közösen szerzett vagyont. A Katonai Határőrvidék polgárosodása (1881) után a házközösségi viszonyok rendezésére 1889-ben egy újabb törvény született. ${ }^{26}$ Ez elismerte a közös, oszthatatlan és elidegeníthetetlen tulajdonú zadruga jogi személyiségét. A felosztásnál részesedésre voltak jogosultak azok a felnőtt korú férfi és nő tagok (mint az egyes családok „fejei”), akiknek felmenői már nem éltek, vagy nem voltak a nagycsalád tagjai. ${ }^{27} \mathrm{~A}$ nő elveszíthette ezt a jogát, ha férjhez ment a zadruga egyik tagjához.

${ }^{21}$ A délszláv zadrugákhoz hasonló közösség máig csak a vándor romák körében maradt meg. A tábor vezetője (shero Rrom/baro shero) egy idősebb, tapasztaltabb és tiszteletben álló férfi, aki gondoskodik az utazók anyagi szükségleteiröl és a közös védelemröl. Ő képviseli a közösséget más romákkal vagy gádzsókkal való kapcsolatokban, a döntéseket pedig a „vénekkel” tanácskozva hozza meg. Nincsenek írásos szabályaik, történeti leírásaik, hanem hagyományaikat egymásnak adják át. Az idősebb korosztály határozza meg, hogy mi a jó és a rossz, mi a „roma” és mi nem az, mi a „férfi” és mi a „nő” joga vagy kötelessége.

22 PÉTERvÁRI, Máté: One Empire and Two Ways of Public Administration: The Second Level Administrative Division in Austria-Hungary. Journal on European History of Law, 2018, 134.

${ }^{23}$ Az 1630. október 5-i „Statusa Valachorum” volt az első szabályzat. HEKA, Ladislav: Vlaški statuti i njihova usporedba s povlasticama mađarskih hajduka. Podravina, 2019/35, 26-45. https://hrcak.srce.hr/223345 (2020. 08. 23.) Ezután következett az 1754. évi „Militärgrenzrechte für das Karlstadter u. Varasdiner Generalat” nevű szabályzat, amelyet 1787-ben a „Systemalverordnung” szabályzat egészített ki. 1807-ben hatályba lépett az „Alaptörvények a károlyvárosi, varasdi, horvát bánsági, szlavóniai és bánsági határőrvidék számára” című szabályzat, végül pedig 1850-ben „A horvát, tót és bánsági szerb katonai határszél számára” címü alaptörvény. Hazánkban az 1873: XXIX., az 1885: XXIV. és végül az 1898: XII. törvénycikkek rendelkeztek a házközösségek fokozatos megszüntetéséröl.

${ }^{24}$ KREŠIĆ, Mirela: Hrvatske kućne zadruge: dioba per linea ili per capita. Pravni vjesnik, 2015/1, 19.

${ }^{25}$ KREŠIĆ: (2015) i. m., 19.; HoMOKI-NAGY Mária: A magyar magánjog történetének vázlata 1848-ig. Szeged, 2010, 86-87.

${ }^{26}$ Zakon od 9. svibnja 1889. o zadrugah, In: Sbornik zakonah i naredbah valjanih za kraljevine Hrvatsku $i$ Slavoniju, 1889, komad VIII, 32, 365-382.

${ }^{27}$ A nők jogairól lásd: KREŠı́c, Mirela: Entitlement of Female Descendants to Property of Croatian Communal Household. Journal on European History of Law, 2011, 73-85. 
A határörvidéki házközösségektöl eltérően a szerb, montenegrói, albán, bolgár vagy bosznia-hercegovinai nagycsaládok közös vagyona (stožer) feloszthatatlan volt, így azt nem lehetett megörökölni, ezért nem is szabályozták az egyes házközösségi tagok részesedési arányát. Az egyke lányt az öröklési sorban megelözték a testvérség és a törzs (mint vérszerinti közösségek) férfitagjai, tehát őt csupán a miraz (a török eredetű miras szó jelentése örökség, jogos követelés, vagyis nem teljesen azonos a hozomány intézményével) és a megfelelő kiházasítás illette meg. ${ }^{28}$ Az ilyen megoldás igazságtalan volt, nem tükrözte az édesapa akaratát sem, hiszen ő valószínüleg azt szerette volna, hogy vagyonát a saját lánya örökölje, és nem valamelyik távoli rokona, akit talán nem is ismert.

Bosznia-Hercegovinában és Montenegróban az özvegyek haszonélvezeti joggal rendelkeztek mindaddig, amíg a férjük családnevét viselték (tehát nem mentek ismét férjhez). ${ }^{29} \mathrm{~A}$ muszlim délszlávoknál (a mai bosnyákok) néha az özvegyasszony férjhez ment a zadruga valamelyik nőtlen tagjához, és ezáltal maradhatott a házközösségben. A keresztényeknél gyakran előfordult, hogy a férj még életében elkülönített a feleségének egy darab földet, bútorzatot, és biztosította számára a lakhatást annak élete végéig. Ezzel elkerülte annak a lehetőségét, hogy nejét a gyermekei önkényének tegyék ki. ${ }^{30} \mathrm{~A}$ bolgároknál (Tirnovo környékén) a gyermektelen özvegy férjének elkülönített vagyonából annak egynegyedét kapta meg, ha pedig voltak gyermekei, akkor az említett vagyon nyolcadrészére volt jogosult. Emellett igényt tarthatott férjének személyes tárgyaira, és a kapott ajándékokra is. ${ }^{31}$

A Balkánon a 20. században kezdődött, és a század második felében befejezödött a zadrugák és vagyonuk felosztása. Azt a nő nem kezdeményezhette, mivel nem rendelkezett tulajdonjoggal, de ha sor került a felosztásra, akkor az ingóságokból (marhák, pénzösszeg) részesülhetett (a földböl nem), a férjezett asszony pedig megtarthatta a mirazt is. Csupán a bolgár Tirnovo környékén részesültek a nők az ingatlanokból is (általában gyümölcsöst vagy szőlőt kaptak). ${ }^{32}$

${ }^{28}$ KREŠIĆ: (2011) i. m., passim.

${ }^{29}$ Bogıšıć, Valtazar: Zbornik sadašnjih pravnih običaja u Južnih Slovena. Gragja u odgovorima iz različnih krajeva slovenskoga juga, knj. I. Zagreb, 1874, 30.

30 Stojanović, Velibor: Prilog poznavanju porodičnih zadruga u rožajskom kraju. Rožajski zbornik, $1985,95$.

${ }^{31}$ KuLAuzov, Maša: Položaj žena u porodičnoj zadruzi prema običajnom pravu Južnih Slovena. Zbornik radova Pravnog fakulteta u Novom Sadu, 2008, 814. http://zbornik.pf.uns.ac.rs/images/download/2008/2008-1/ doi_10.5937_zrpfns42-0046.pdf (2020. 08. 28.).

32 Más népeknél kivételesen a nő is betölthette a sztaresina szerepet, ha a házközösségben nem volt felnőtt férfi. Ekkor ő képviselte a családot a hatóságoknál, igazgatta a házközösséget, elvégezte a munkabeosztást, és a zadruga tanácsával együttmüködve rendelkezett a családi vagyon felett. Azonban a házközösség és a közös vagyon megóvása miatt a nő nem örökölhette a földet, emellett a patriarchális felfogás szerint a család „nevét” is csak a fiúgyermek vihette tovább, ezért a „női” családnevek, mint például a Marics, Katics, Sztanics, Anics, Ruzsics (Mara, Kata, Sztana, Ana, Rózsa „fiú utódai”) tanúskodnak arról, hogy egyes családokban nő volt a sztaresina. Azonban ezt a szerepet csak ideiglenesen tölthette be, addig, amíg a férfi családtagok nem váltak felnőtté, vagy amíg a családba nem került egy irányítani képes férfi. BogıŠı́: (1874) i. m., 32-34.; Bogıšıć, Valtazar: Pravni običaji u Crnoj Gori, Hercegovini i Albaniji (Anketa iz 1873 .g.), prir. Tomica Nikčević, CANU, Titograd, 1984, 25.; KULAUZov: i. m., 809.; NovAKovıć, Nada: Teorije o nastanku i strukturi porodičnih zadruga. Stanovništvo 43, 2005, 108. http://www.doiserbia.nb.rs/img/doi/0038-982X/2005/0038982X0504105N.pdf (2020. 08. 23.). Szerbiában ilyenre nem volt jogi lehetőség. 
Ha leánygyermek maradt a zadruga utolsó tagja, akkor ő a teljes vagyont megörökölte, de a házközösség fennmaradásához szükség volt arra, hogy férjhez menjen egy vagyontalan fiúhoz.

Az elmondottakból kitúnik, hogy a horvátországi és vajdasági zadrugák jogi személyek voltak, a házközösségben a nök is részesedhettek a közös vagyonból, amely a törvény szerint felosztható, amíg az Oszmán Birodalom területén létező balkáni zadrugakban a nőket kizárták a vagyonszerzésből. A másik fontos különbség abban látható, hogy a határőrvidéki nagycsaládi közösségek eredetileg katonai hübéri birtokok voltak, amelyeket zsold helyett engedtek át a nagycsaládok tagjainak. ${ }^{33}$ Hazánkban ez az intézmény a sajkások kerületében terjedt el leginkább, egészen az 1885:XXIV. tc-ig, amikor megszűntek. ${ }^{34}$ Ezek a zárt, önellátó, naturális gazdálkodású közösségek ugyanis gátolták a parasztság fejlödését, a közös birtoklás pedig gyökeres ellentétben állt a tulajdon polgári fogalmával, hiszen sem a választott családfö, sem a tagok nem rendelkezhettek szabadon a birtokkal, hanem azt csak közös megegyezéssel és hatósági engedéllyel lehetett felosztani, elárverezni, megterhelni. ${ }^{35}$

\section{A nők jogi helyzete a zadrugában}

A zadruga patriarchálisan müködött, a nök szerepe másodlagos volt. A szokásjog értelmében feladataik közé tartozott a háztartás vezetése, a gyermeknevelés és a házimunkák elvégzése. A házközösségen belül hierarchia állt fenn a férfiak és a nők oldalán egyaránt. A mater familias gondoskodott a gazdaságos házvezetésről, az asszonyok közötti kisebb konfliktusok megoldásáról, ő osztotta el a nőknek a feladatokat. Minden asszonynak engedelmeskednie kellett neki és tisztelnie őt. Általában a „sztaresina” felesége, ritkábban édesanyja látta el ezt a feladatot, illetve ha azok megöregedtek, akkor egy bölcs és tapasztalt asszonyra bízták a házvezető nő szerepét. Egy ilyen döntést csak a pater familias vagy a házközösségi tanács (a felnőttkorú férfiak) hozhattak meg szavazattöbbséggel. A nők nem vettek részt az ingatlanokról és a jogi ügyletekröl szóló döntéshozatalban, az csak a férfiakat illette meg. Csupán véleménynyilvánítási joguk lehetett, szavazni kizárólag a nagycsalád házimunkájával kapcsolatos kérdésekben volt joguk.

A szerbeknél a feleség helyzetét súlyosbította az a tény, hogy sem a szülöi házban, sem a férj családjában nem volt vagyona, a munkáját nem értékelték és nem is

${ }^{33}$ Emellett különbségként megemlíthetjük azt is, hogy a Horvátország északi és középső területén müködő házközösségek átlagban 5,4 föböl álltak, amíg a Balkán délebbre eső részeiben legalább húsz főt számláltak a zadrugák. ČAPO ŽMEGAČ, Jasna: Konstrukcija modela obitelji u Europi i povijest obitelji u Hrvatskoj. Narodna umjetnost, 1996/2, 190.

${ }^{34}$ BoRovszky Samu: Magyarország vármegyéi és városai. Bács-Bodrog vármegye I. Házközösség. https:/l www.arcanum.hu/hu/online-kiadvanyok/Borovszky-borovszky-samu-magyarorszag-varmegyei-es-varosai-1/ bacs-bodrog-varmegye-i-163F/bacs-bodrog-varmegye-nepe-1E47/4-szerbek-1F7F/hazkozosseg-1FB8/ (2020. 08. 28.).

${ }^{35}$ Katus László: A mezőgazdaság tőkés fejlődésének föbb vonásai az Osztrák-Magyar Monarchia délszláv lakta területein. Történelmi Szemle, 1959, 371. 
fizették meg. Ezért van, aki még a szolgálólány jogállását is kedvezőbbnek tartotta, mert annak munkáját legalább fizetéssel honorálták. ${ }^{36}$ Egyedül azzal a vagyonnal rendelkezhetett önállóan (eladhatta, elajándékozhatta vagy más módon elidegeníthette), amelyet a házközösségen kívül végzett munkával szerzett. ${ }^{37}$ Bár a szerb Ptk. többnyire nem vette át az Optk.-nak a nők jogaira vonatkozó szabályait, a miraz formájában legalább a hozomány intézményét beépítette a szerb jogrendszerbe. ${ }^{38}$ Azonban ezzel a - tulajdonában lévő - hozománnyal a férj rendelkezett, azt meg kellett tartani (őrizni) a gyermekeknek (akik azt majd anyjuk halála után örökölték). ${ }^{39}$ Úgyszintén a házasság fennállása alatt szerzett vagyont is a férj kezelte, így a feleség csakis férjének engedélyével rendelkezhetett róla.

Montenegróban és Hercegovinában ezen kívül a nőknek lehetősége volt további keresetre is, amennyiben a szükséges házi munkák elvégzése után a sztaresina engedélyezte, hogy elmenjenek napszámba dolgozni egy másik házközösségbe. ${ }^{40}$ A napszám díja saját vagyonukat képezte, amellyel önállóan rendelkezhettek. Eleinte csak a szegény házközösségekben fordult elő az ilyen eset, és a nők megélhetését célozta, majd a 19. század végén már a saját család anyagi helyzetének javítására szolgált.

\section{Házassági jog}

A délszláv térségben élő nők eltérő jogállása abból adódott, hogy különböző országokhoz, jogrendekhez, vallásokhoz tartoztak. Jogi helyzetükre nagy hatást gyakorolt a vallási hovatartozásuk, mivel a házassági köteléki jog egyházi jogalkotási és jogalkalmazási hatáskörbe tartozott. A katolikus és pravoszláv keresztények egyházi előírásaikat, a muszlimok a shari'a jogot alkalmazták.

\subsection{A katolikus házasság}

A házassági jog terén a horvátok (Horvátország, Szlavónia, Dalmácia) számára az Optk. (horvátul Opći građanski zakonik, OGZ) mellett a Corpus luris Canonici és az egyházi bíróságok működésének irányelvei voltak a mérvadók. ${ }^{41}$ Házassági akadályok voltak: a beleegyezés hiánya, a házastársi kötelezettség teljesítésének

${ }^{36}$ STANKović: i. m., 414-415.

${ }^{37}$ Bogıšı́: (1874) i. m., 106-109.; Bogıšı́c: (1984), i. m., 99.

${ }^{38}$ STANIMIRović, Vojislav: Snaga običaja - porodica u Srpskom građanskom zakoniku između starog i novog. In: Srpski građanski zakonik - 170 godina, Beograd, 2014, 145-166.; STANIMIRović, Vojislav: Ustanova miraza u našoj tradicijskoj kulturi. Beograd, 1988; STANIMIRović, Vojislav: Brak i bračna davanja u istoriji. Beograd, 2006.

${ }^{39}$ HeRger Csabáné: A modern magyar házassági vagyonjog kialakulása és rendszere a német jogfejlődés tükrében. Passau, 2017, 282-302.

${ }^{40}$ Az Osztrák-Magyar Monarchián (Horvátország, Dalmácia és a Katonai Határőrvidék) kívül Bulgáriában is elöfordulhatott az ilyen eset.

${ }^{41}$ Opći austrijski građanski zakonik, proglašen patentom 29. studenoga 1852. u Kraljevinama Hrvatskoj i Slavoniji, uredio F. J. Spevec, Zagreb, 1899, 24-25. 
hiánya, továbbá az erkölcsi tilalom (már meglévő házasság), felszentelés vagy fogadalom, illetve vallási különbség. ${ }^{42}$

Jóllehet Horvátország Magyarországgal államközösséget alkotott, a horvát-magyar kiegyezésröl szóló 1868:XXX. törvénycikk értelmében a házassági jog belügynek számított, így a magyarországi polgári házasságról szóló 1894:XXXI. törvénycikk nem volt hatályos a „társországokban." ${ }^{43} \mathrm{~A}$ katolikus horvátok számára a házasság szakramentum, „Isten akarata és kegyelme szerinti teljes és felbonthatatlan életközösség férj és felesége között." "44 Horvátországban és Szlavóniában csakis az egyházjogot alkalmazták a házasság érvénytelenségének, valamint az ágytól és asztaltól való elválasztásnak a kérdéseiben. Az 1856 évi császári pátens 57. §-a rögzítette, hogy ha az egyik házastárs horvát honosságú (magyar állampolgár) és katolikus vallású, akkor nem bontható fel a házassága még akkor sem, ha időközben más vallásra tért volna át. Ha Magyarországon mégis felbontották a házasságot és új frigyet kötött, akkor a horvát jogrend szerint a bigámia bűntettét követte el. Habár a császár 1870. július 30-án érvénytelennek nyilvánította az 1855. évi konkordátumot, a pápa azt nem helyezte hatályon kívül, így a katolikusok továbbra is alkalmazták.

XV. Benedek pápa 1917. május 27-én hírdette ki a Codex luris Canonicit, amely 1918. május 19-én lépett hatályba. Egészen 1946-ig, a szocialista Jugoszlávia megalakulásáig alkalmazták. Ekkor Horvátországban bevezették a kötelező polgári házasság intézményét.

\subsection{A pravoszláv házasság}

A szerb Polgári Törvénykönyv hatályba lépése után a házassági köteléki jogban a felekezeti jog továbbra is érvényben maradt. A pravoszláv egyházjogban a házastársak jogainak és kötelességeinek jogi alapja a két ellenkező nemü személy között egy pap és két vagy három tanú elött a pravoszláv egyház törvényeivel összhangban megkötött házasság volt. ${ }^{45} \mathrm{~A}$ házasulandó felek beleegyezésének bizonyítására

42 LovRIć, Edo: Ženidbeno pravo. Zagreb, 1911, 28-33.; ALINČıć, Mira: Građanski brak sklopljen prema državnim propisima i vjerskom obredu. Zbornik Pravnog fakulteta u Zagrebu, 1997, 661-662.

${ }^{43}$ A szerző művei közül lásd HEKA László: A horvát-magyar kiegyezésröl. Az 1868:I. tc. illetve az 1868:XXX. tc. elemzése. Jogtudományi Közlöny, 1997, 131-141.; HEKA László: Az 1868. évi horvát-magyar kiegyezés a sajtó tükrében. Acta Jur. et Pol. Tom. LIV, Fasc. 9, Szeged, 1998, 3-39.; HEKA, Ladislav: Osam stoljeća Hrvatsko-ugarske državne zajednice s posebnim osvrtom na Hrvatsko-ugarsku nagodbu. Szeged-Subotica, 2011; HEKA, Ladislav: Hrvatsko-ugarska nagodba u zrcalu tiska. Zbornik Pravnog fakulteta Sveučilišta u Rijeci, 2007, 931-971.; HEKA, Ladislav: Hrvatsko-ugarski odnosi od srednjeg vijeka do Nagodbe iz 1868. s posebnim osvrtom na pitanje Slavonije. Scrinia Slavonica, 2008, 152-173.; HEKA, Ladislav: Hrvatsko-ugarski javnopravni prijepori. Zbornik Pravnog fakulteta u Zagrebu, 2013, 1257-1292. A polgári házasságról (matrimonium civile) szóló törvényt a mai Horvátország területén csak a Drávaszögben és a Muraközben alkalmazták (Magyarország akkori territóriumán).

${ }^{44}$ DoBrovŠAK, Ljiljana: Ženidbeno (bračno) pravo u 19. stoljeću u Hrvatskoj. Croatica Christiana periodica, 2005, 78.

45 PALAČKović, Dušica: Crkveno pravo i Srpski građanski zakonik. In: 150 godina, Niš, 1994, 35-44.; CvEJIĆJANČıć, Olga: Roditeljsko pravo u Srbiji prema Srpskom građanskom zakoniku iz 1844. g. Zbornik Pravnog fakulteta u Novom Sadu, 2004, 361-381.; AvRAmović: i. m. 34-35. 
a szerb Ptk. előirt egy vizsgát (vizsgálatot) a pap előtt, amíg az Optk. a házasságkötés előtti kihirdetést és az ünnepélyes nyilatkozatot tette kötelezővé.

A házastársak az esküvőn hüségre és örök szerelemre tettek esküt (60. §). ${ }^{46}$ A házasságra senkit sem lehetett kényszeríteni (66. §). ${ }^{47} \mathrm{Az}$ esküvő előtti ajándékozás (jegyajándék) nem jelentett jogi kötelezést a házasságkötésre, de a törvény úgy rendelkezett, hogy a megajándékozott fél addig nem tárgyalhat más ,jelölttel”, amíg a kapott ajándékot vissza nem adja (61-62. §). ${ }^{48}$ Házassági akadályok voltak: a már meglévő házassági kötelék fennállása, a kor (a kiskorúak felmenthetők az illetékes püspöktől kapott engedéllyel, a szülők illetve a gyámok beleegyezésével), a törvényben tiltott rokonsági kapcsolatok, a házastársi feladatok ellátására való képtelenség, pszichés betegség fennállása, a rablás vagy kényszer esete, megfélelmítés által szerzett beleegyezés, továbbá a csalás, a börtönbüntetés letöltése, a keresztény és nem keresztény közötti frigy (69. §).

1918 után a pravoszláv lett az államvallás, a joghatóság pedig a Szerb Pravoszláv Egyházat illette.

\subsection{A házasság felbontása a pravoszláv egyház joga szerint}

A szerb pravoszláv házassági törvény rendelkezett a házasság megszűnésének eseteiről. Az egyik házastárs halála mellett a frigyet válással is fel lehetett bontani, mégpedig az úgynevezett szubjektív bontóokok miatt: házasságtörés, a házastárs élete ellen elkövetett büncselekmény, nyolc évnél hosszabb időtartamú jogerős börtönbüntetés, vagy ha az egyik fél elhagyta a keresztény vallást, illetve az eltünés és elrejtőzés esetén. Ha az eltünésre vétlenül került sor, akkor a másik fél hat év elteltével kérhette az egyházi bíróságtól a bontás kimondását. ${ }^{49} \mathrm{~A}$ bíróság ezután a világi hatóságok közremüködésével megkereste az illetőt, és ha az egy éven belül nem jelent meg, akkor a másik félnek engedélyezték az új házasság megkötését. Amennyiben ezután az eltűntnek vélt házastárs visszatért, jogában állt „visszavenni a feleségét" (azaz annak új házassága érvénytelenné vált), vagy ha ezzel nem élt, ő maga is új házasságba léphetett. ${ }^{50}$

Azonban, ha a házastárs a hatóságok tudta nélkül megszökött a hazájából vagy ismeretlen helyre távozott, ekként akarva elhagyni a feleségét, akkor az asszony az első esetben négy, a második esetben három év várakozási idő után kérelmezhette

\footnotetext{
${ }^{46}$ Sveti arhijerejski sinod: Bračna pravila Srpske pravoslavne crkve (A Szerb Pravoszláv Egyház házassági szabályai). Beograd, 1994. A tárgyi házassági szabályokra vonatkozóan bővebben lásd PERIć, Dimšo: Zakonodavstvo Srpske pravoslavne crkve od stvaranja Jugoslavije do novijeg vremena. Prilog proučavanju odnosa Crkve i države. Srpska pravoslavna eparhija kanadska, Toronto, 1995, 196-248.; MEJENDORF, Jovan: Brak u svetlosti pravoslavne teologije. Teološki pogledi, 1974, 153-207. https://teoloskipogledi.spc.rs/ sr/VII.1974 (2020. 08. 28.).

${ }^{47}$ Bračna pravila Srpske pravoslavne crkve, 66. §.

${ }^{48}$ Bračna pravila Srpske pravoslavne crkve, 61-62. §.

${ }^{49}$ A bontás kimondása előtt a felek békítési eljáráson vettek részt egy egyházi személy közvetítésével. Ha a háromszor megkísérelt békítés eredménytelen maradt, akkor az eljárás az egyházi bíróság előtt folytatódott, amely kimondhatta a kötelék felbontását (99. §).

${ }^{50}$ Bračna pravila Srpske pravoslavne crkve, 95. §.
} 
a házasság felbontását. Az egyházi bíróság ugyanazt az eljárást folytatta le, mint a házastárs vétlen eltűnésekor (tehát egy év elteltével a fel nem bukkant házastárs eltűntnek számított, és a másik fél új frigyet köthetett). Ha a házastárs ezután megjelent, e ténynek már nem volt hatása az új házasságra, mert az érvényes volt, és az is maradt.

Semmisnek számított ugyanakkor az olyan házasság, amelynél egy férfi - élő törvényes felesége mellett - más nőt vett el feleségül. Ilyen esetben köteles volt ez utóbbit elbocsátani. Ha a mennyasszony nem tudta, hogy törvényellenes (tilalmas) házasságra lépett, akkor a férfi köteles volt családjának kártérítést fizetni, beleértve az okozott szégyent és sérelmet is. A férfi ezen kívül büntetőjogi felelősséggel is tartozott, ahogy az eskető pap is, amennyiben tudomása volt arról, hogy a férj már házas. ${ }^{51}$

A házközösségekben a válás ritkán fordult elő, mert azt a nagycsaládnak okozott szégyennek tartották. Ha arra mégis sor került, akkor a közös vagyont egyforma részekre osztották fel a házastársak között, amíg a miraz a nőt illette. A felnőtt fiúgyermekek az édesapjuknál maradtak, a felnőtt leánygyermekek és az egészen kicsi gyermekek (nemükre tekintet nélkül) az édesanyjukkal együtt elköltöztek az anyai szülöházba. ${ }^{52} \mathrm{Az}$ apa köteles volt eltartani a leánygyermekeit és kiházasítani őket a meglévő szokásoknak megfelelően, a fiú kisgyermekek pedig felnőtté válásuk után visszatérhettek az apjuk házközösségébe.

\section{A szerb feleség jogállása}

A szerbeknél a leánygyermeknek joga volt „tisztességes elhelyezésre, ellátásra és tartásra." ${ }^{53}$ Ha nem akart férjhez menni, csupán a haszonélvezeti jogát érvényesíthette. Kivételes esetben a testvérség tagjai engedélyezhették neki, hogy férjével éljen a vagyonában, és új családi zadrugát alakítson. ${ }^{54} \mathrm{~A}$ legalacsonyabb személyi jogi jogállásuk a szerb házas nőknek volt, amiről a szerb Ptk. 108., 109. és 110. §-ai rendelkeztek. ${ }^{55}$ Egyebek közt cselekvőképességgel sem bírtak, hanem a férjük képviselte őket. E tekintetben egyesek a jogállásukat a kiskorúakhoz és a gyengeelméjüekhez hasonlítják. ${ }^{56}$ Alárendeltségük föként az öröklési jogban jutott kifejezésre: először a férfi utódok és azok utódai örököltek (a hatodik ágig), majd csak azután kerülhetett sor a nőkre. ${ }^{57}$

\footnotetext{
51 Bračna pravila Srpske pravoslavne crkve, 71. §.

52 Bogıšić: (1874), i. m., 106-109.; Kulauzov: i. m., 810.

${ }^{53}$ Erről a fiú örökös döntött, így elképzelhető, hogy egyes esetekben az örökölt vagyon egyes tárgyait vagy pénzösszeget elrejtették, hogy azokon ne kelljen osztozni a leánytestvérükkel. A fivér a pénzösszeget vagy vagyontárgyat inkább a saját fiára vagy lányára hagyta, mint a nővérének vagy húgának. Példák vannak arra, hogy az anyós sem akarta a menyének adni a családi vagyontárgyakat.

${ }^{54}$ Bogıšıć: (1874), i. m., 354-356; Bogıšıć: (1984), i. m., 112.

${ }^{55}$ BožınoviĆ, Neda: Žensko pitanje u Srbiji u XIX i XX veku. Beograd, 1996, 73-74.

56 DrAskić, Marija-Popvić-OBRAdović, Olga: Pravni položaj žene prema Srpskom građanskom zakoniku. In: Perović, Latinka (szerk.): Srbija u modernizacijskim procesima XIX i XX veka: Položaj žene kao merilo modernizacije 2. Beograd, 1994, 15.

${ }^{57}$ Kulauzov: i. m., 815.
} 
Az 510. § részletezte, hogy a közös vagyonnal rendelkezni, azt eladni vagy megterhelni csak valamennyi felnőttkorú és nős férfi hozzájárulásával lehet. Ezzel kapcsolatosan megoszlott a vélemény, hogy a szerb nők egyáltalán lehetnek-e a zadruga tagjai. A belgrádi Semmítőszék 1871. október 6-án kelt 2955. számú határozata expressis verbis kimondta, hogy a nők nem rendelkeznek tagsággal, viszont az 1212. számú 1877. május 27-i határozatában ugyanez a bíróság azt állapította meg, hogy a leánygyermekek öröklésére vonatkozóan a házközösségröl szóló rendelkezések az irányadók." ${ }^{58}$ A legfőbb bírói fórum álláspontja tehát nem volt egységes. A többségi vélemény szerint azonban a feleség nem volt a zadruga tagja, emiatt kizárt volt, hogy sztaresina legyen. ${ }^{59}$

Jóllehet a feleség nem dönthetett a zadruga kérdéseiröl, nem befolyásolhatta a nagycsalád életét és müködését, az általa végzett munkát kisebb értékünek, csekélyebb jelentőségűnek tartották, mégis a nőket okolták a kollektív tulajdonú, patriarchális közösség felbomlásáért. Erre csak a 20. században került sor, amikor az egyes családok és azok saját vagyona erősebb kötelék lett a vérségen alapuló kollektív vagyonnál és tudatnál.

\subsection{A miraz}

Az Osztrák-Magyar Monarchia területén fennállott zadrugákban a nők mirazként (általában hozományként fordítjuk) nemcsak ingó vagyontárgyakat hoztak, mint a Balkánon (az Oszmán Birodalomban), hanem olykor ingatlanokat is. A tulajdonukat képező vagyon elnevezése osobac (peculium) az osoba (személy) szóra vezethető vissza. Azt fejezi ki, hogy a szülői házból hozott marha, birka, kecske vagy más haszonállat a nő „személyes” tulajdona, vagyis a házközösség ellenőrzésén kívül esik. Később a női vagyonra a miraz (a török miras és az arab mīrat szóból, amelynek jelentése: örökség) illetve a muszlim környezetben a „sermija” kifejezés lett az elterjedtebb. A római és a bizánci jogból átvett miraz (dota) intézményét Raguza (Dubrovnik) tette népszerúvé.

A horvát kulturális, tudományos és müvészeti élet „hazájának” számító városállam már 1235-ben határozatot hozott a házasságról és a hozományról (Ordo de dotibus et nuptiis), amelyben előírta, hogy annak értéke legfeljebb 200 perpera pénzöszszeg és tíz uncia arany lehetett. Aki ezt a szabályt megszegte, annak a büntetése 29 évre szóló kiközösítés volt. ${ }^{60}$ Az egyházi és városi jog értelmében a fent leírt pénzösszegböl, ékszerekből, ruházatból és házi felszerelésből álló dota a házasságkötés kötelező eleme volt. A vagyonnal a férj rendelkezett, a nő tulajdona valójában matrominiális jellegű volt, azt meg kellett őrizni az utódok (örökösök) számára. Az asszony csak végrendeletben rendelkezhetett a miraz egynegyedéröl, illetve feléröl akkor, ha nem voltak gyermekei. Az 1272 évi városi statútum (Liber statutorum

58 StANIMIROVIĆ: (2014) i. m., 151.

59 STANIMIROVIĆ: (2014) i. m., 152.

60 Janeković Römer, Zdenka: Prćija (miraz, dota). In: Leksikon Marina Držića. https://leksikon.muzej-marindrzic. eu/prcija-miraz-dota/ (2020. 08. 28.). 
civitatis Ragusii compositus anno 1272) kötelezővé tette a mirazról szóló szerződés írásba foglalását. ${ }^{61}$

Egyesek vitatják, hogy a fenti fogalmak valójában ugyanazt jelentik-e, mivel az osobac lehetett férfi és nő tulajdona, ingatlan és ingóság, vele szemben a sermija csak a nő tulajdonában lévő ingóságot jelentett, amíg a miraz női tulajdonú ingóság, illetve a horvátoknál akár ingatlan is lehetett. Azt a házasságkötés alkalmával a feleség családja adta a házastársaknak. Ha a lány a szülőfalujában ment férjhez, akkor egy földdarabot (legelő, szőlő, kaszáló) is vihetett hozományként házasságba, ha viszont a férje más településen élt, akkor pénzösszeget hozott a frigybe. A miraz értékéről a leánykérésnél állapodott meg a vőlegény és a leány édesapja. Nem lett a közös vagyon része, hanem a nőé maradt, a férj csak kezelője és haszonélvezője lehetett. Ez a jogintézmény megalapozta a fiatal pár háztartását, de egyben a megözvegyült nő egzisztenciális minimumát is képezte, amennyiben a közös vagyonból nem részesülhetett. Gyakran a miraz a feleség örökségi része volt, aki később már nem örökölhetett. ${ }^{62} \mathrm{~A}$ hozományt lehetett hasznosítani (például bérbe adni), majd tulajdonosának halála után a fiúutódokra szállt. Magyarországon Zala megyében is ismert volt ez az intézmény. Jellemzően a sermija is bérbeadható volt, mert nem ritkán a sztaresina ellenezte, hogy az bekerüljön a házközösségbe. Ezért a nő tulajdonában lévő tehenet, marhát bérbe adták (kesim törökül: bér, bérleti dij) más zadrugának két-három évre. Ennek fejében bizonyos pénzösszeget vagy tejtermékeket kaptak a bérlőtöl. Az ilyen vagy hasonló jogügyletből szerzett bevételt (pénzösszeget) a tulajdonos leánygyermekeinek tartására fordította. ${ }^{63}$

Szerbiában az osobina általában egy pár libából, pulykából, egy-két sertésből, néhány birkából állt, illetve ritkán bárányból vagy tehénből. A miraz törvénybe iktatása után a feleség által hozott érték (tárgyak vagy állatok) az ő tulajdonában maradt, amelyet nevében a férj kezelt. A házközösség eleinte nem ismerte el ezt a vagyont, de idővel tolerálni kezdte, föként válság idején, amikor a házközösség „,hozzányúlhatott” az egyéni vagyonhoz. Erre akkor került sor, ha a sztaresina nem tudta biztosítani a megélhetést a házközösség minden tagja számára (a ruhát és a lábbelit minden család magának szerezte meg). ${ }^{64}$ Ekkor a mirazba hozott jószágokat is bérbe adhatták, vagy azok tulajdonosai partneri kapcsolatot létesíthettek a házközösséggel. Erre azért volt szükség, mert a jószág etetése költséges volt, így a zadruga szemére hányta a tulajdonosnak, hogy ez az ő terhére történik. A vita elkerülése érdekében szokásossá vált, hogy az eledelt a házközösség adta, az időközben született jószágot fele-fele arányban osztották el a nő családja és a

\footnotetext{
61 Janeković Römer: i. m.

${ }^{62}$ Horvátországban a latin dos, valamint az olasz dote szó alapján dota név alatt vált ismertté, föként a tengerparton. Szlavóniában, Vajdaságban, illetve az Alföldön stafirungnak (štafirung, a német Staffierung szó alapján) nevezték a mennyasszonyi hozományt, amelyet azonban általában csak ágyneműk, ruhák, törölközők párnák, takarók, lepedők, kendők, abroszok stb. képeztek, illetve az azok tartására szolgáló ládák, bútorok, néha akár tányérok és ezüst étkészlet is. Magyarországon az általános elnevezés a kelengye volt.

63 STOJAKović, Velibor: Imovina žene u sistemu zadružne svojine. Beograd, 2005, 47.

${ }^{64}$ ARDAlić, Vladimir: Bukovica, narodni život i običaji. Zbornik za narodni život i običaje Južnih Slavena, Jugoslavenska akademi ja znanosti i umjetnosti, knj. V., Zagreb, 1900, 1-50., illetve knj. XI, Zagreb, 1906, 169-170.
} 
házközösség között. Idővel gyarapodott az egyes családok vagyona, ami erősítette a házastársak és gyermekeik egymás közötti szorosabb kötődését, és elősegítette azok önállósodását, elszakadását a zadrugától. A szerb házközösség felbomlása a két világháború között kezdődött, amiért - amint ezt már említettük - a nőket tartják felelősnek (még a népi mondákban is).

A szerb Ptk. 762. § elöírta, hogy a férj nem követelheti a mirazt, ha az a házassági megállapodásban nincs rögzítve, sem megígérve. Ennek ellenére csakhamar Szerbiában is meghonosodott a miraz, és a következő száz évben a házasságkötések szinte nélkülözhetetlen elemévé vált. ${ }^{65}$ Mivel a nő részéről házasságba hozott vagyont a férj kezelte, a szerb jogrend specifikuma lett az a kötelesség, hogy a hozomány biztosítására törvényes jelzálog terhelte a férj vagyonát (776. §).

\section{A házas nő személyi és vagyoni állása az 1844. évi szerb polgári törvénykönyvben}

A Ptk. szerint a háznagy a „ház” és a rokonság feje, az, aki köteles vezetni a vagyoni közösséget („háza népét”), gondoskodni feleségéröl, megvédeni őt, ellátni minden szükségessel, és képviselni őt (109. §).

„A feleség köteles hallgatni a férjére, teljesíteni a parancsait, őt követni, és ahol a férje jónak látja, ott vele letelepedni és élni. Erejéhez képest segíteni kell neki a házi munkák elvégzésében, a vagyon gyarapításában és megőrzésében, valamint fentartani a házirendet és a ház tisztaságát, törődni a gyermekekkel és tisztaságra és jóra nevelni őket” (110. §).

A feleség alárendelt volt a férjének, amíg ő a házban volt, a feleség nem szólalhatott meg, férje nevét más emberek előtt meg sem említhette. ${ }^{66}$

A nők másodrendű jogállására utal az a tény is, hogy a szerb törvénykönyv az Optk.-ból átvette a kártérítésre vonatkozó rendelkezések (1293-1340. §) többségét, de az 1328. §-t § nem. Márpedig az előírja:

„Ki valamely nőszemélyt elcsábít, s vele gyermeket nemz, megfizeti a szülés és gyermekágy költségeit és az első rész harmadik fejezetében megállapított atyai kötelességeket teljesitendi. Mely esetekben kelljen az elcsábítást, mint egyszersmind büntettet, vagy súlyos rendőri kihágást büntetni, a büntető törvény foglalja magában."67

65 JUNG Károly: Délszláv adatok a házassági szerződések és hozománylevelek egybevető vizsgálatához. In: Bordás Győző (szerk.): Köznapok és legendák. Forum, Újvidék, 1992, 37-44. https://adoc.pub/jung-karolydelszlav-adatok-a-hazassagi-szerzdesek-es-hozoma.html (2020. 08. 28.) Jung arról ír, hogy a délszláv térségben a Velencei Köztársaságból átvett intézmény Kotor (latinul: Cathar, olaszul: Cattaro) és Herceg Novi területén a 15-16. században jelent meg. Onnan vették át a montenegróiak és a hercegovinaiak, és így terjedt el a déli szlávok között. Kiemeli, hogy a mirazt hozománynak fordítjuk, de valójában a két intézmény nem azonos. CRNIć, Marija: Prćija po dokumentima iz hercegnovskog arhiva. Glasnik Etnografskog muzeja, 1963, 283-294.; KuLıŠıć, Špiro: Etnološka istraživanja u Boki Kotorskoj. Beograd, 1953.

${ }^{66}$ Hasonló függőségi viszony figyelhető meg a 18. századi bajor kódexben is. HERGER: i. m., 82-83.

${ }^{67}$ Márkus Dezső (szerk.): Az Osztrák Általános Polgári Törvénykönyv mai érvényben. Budapest, 1907. http:/l mek.oszk.hu/13200/13288/13288.pdf (2020. 08. 23.). 
E rendelkezés mellőzésének oka lehetett egyrészt az, hogy a házasságon kívül született gyermek az egész család és rokonság számára szégyent jelentett. Ezért igyekeztek azt eltitkolni, vagyis bírósági pert ez ügyben nem indítottak volna. Másrészt a hivatásos bábák csak a városokban asszisztáltak a szülésnél, a falvakban a családon belül segítettek a nők egymásnak, ezért a gyermekágyi költségek elenyészők voltak. ${ }^{68}$ Mivel tehát az ilyen szülés szégyent jelentett, amely esetleg ellehetetleníthette a lány későbbi házasságát, ezért azt eltitkolták, a megszületett gyermeket pedig nem ritkán a templom ajtaja előtt hagyták. A szerb társadalomban ritkán fordult elő, hogy egy lány ne menjen férjhez (legfeljebb például testi fogyatékosság miatt történhetett ilyen), és azt balszerencsének tartották. ${ }^{69}$ A férfitől a család elvárta, hogy egy lány teherbe ejtése esetén vegye el feleségül, a botrány elkerülése érdekében. Ezért a bírói gyakorlatban sem fordult elő jelentősebb számban a kártérítési igény. ${ }^{70}$ Megjegyzendő, hogy az egyház a paráználkodást súlyos bűnnek tartotta.

A törvény hatályának kiterjesztését illetően a 48. § kimondta, hogy „Törökország bámelyik területéről származó és Szerbiában férjhez ment asszony honpolgárnak tekintendő, éppúgy, ahogy egy szerb nő, aki Törökország más területén férjhez megy, ott szintén honpolgárnak számít."

A Ptk. különbséget tett a gyermekek között az alapján, hogy törvényesek (akik a házasságkötést követő 180 nap után, illetve a férj halálát követő 300 napon belül születtek), házasságon kívüliek, vagy örökbefogadottak (112. §). Az édesapa volt a gyermekek képviselője minden hivatalos eljárásban (126. §). Ha nem teljesítette a szülői kötelességeket, akkor helyébe a házközösség feje (a sztaresina) lépett, mivel ő egyébként is felelt az egész "ház” cselekményeiért (116. §). A gyermektartáshoz való jog megillette a fiút felnőtt koráig (a 21. életév betöltéséig), a leánygyermeket pedig férjhez meneteléig (117. §). A házasság felbontása esetén a fiúgyermekek négy-, a leánygyermekek hétéves korukig az édesanyjuknál éltek, utána az édesapához kerültek (118. §). A nevelés költségei elsősorban az apát terhelték, utána az édesanyát, majd az apai nagyszülöket, ezt követően az édesapa férfi testvéreit (nagybátyákat, a déli szlávoknál: stric), s végül az anyai nagyszülőket. Öket követték az édesanya fiú testvérei (nagybátyák, a déli szlávoknál: ujak). Amennyiben a felsorolt férfiak (nagybátyák) a zadruga tagjai voltak, akkor a ház feje gondoskodott a gyermekek eltartásáról is. ${ }^{71}$ A gyermekeknek engedelmeskedniük kellett a szülöknek, és tisztelniük kellett őket. Szülői engedély nélkül semmilyen jogi ügyletbe nem bonyolódhattak. Az öreg vagy tehetetlen, illetve szegénységben élő szülőket a gyermekeknek el kellett tartaniuk. A házasságon kívül született gyermek neveléséről az édesanya gondoskodott. Ha ő nem tudta ellátni a feladatait, akkor sorban következtek az édesapa illetve a „ház” és a rokonág (131. §). Ha nem ismerték el őket törvényes (házasságban született) gyermekeknek, akkor nem rendelkeztek polgári jogokkal (133-134. §). Az örökbefogadottak a törvényes gyermekekkel azonos jogokkal bírtak (137-140).

\footnotetext{
${ }^{68}$ KATANČEviĆ, Andreja: Troškovi porođaja. In: Srpski građanski zakonik - 170 godina. Beograd, $2014,344$.

69 KATANČEVIĆ: i. m., 346-347.

70 KATANČEVIĆ: i. m.

71 JovANOVIĆ, Aleksa S.: Zadruga po propisima našeg Građanskog zakonika. Glasnik Srpskog učenog društva, 1872, 220-271.
} 
A feleség eltartásra volt jogosult férjének vagyonából özvegyként is, ameddig a családnevét viselte, függetlenül attól, hogy hanyadik felesége volt (412. §). Ha férjhez ment vagy meghalt, akkor a vagyon az elhunyt férj törvényes örököseire szállt át (415. §). Amennyiben az egyik házastárs megölte a másikat, vagy tudott arról, hogy a házastárs gyilkosságra készül, akkor nem örökölhetett utána (419. §). Az önvédelemből vagy kényszerhelyzetben elkövetett emberölés nem számított ilyen akadálynak (421. §). Végrendeletet készíthetett férfi is és nö is (428. §), de a szerb nő nem lehetett tanú végrendeletnél, valamint gyám sem (kivéve, ha saját gyermekeiről lett volna szó, tehát azok apjának halála esetében).

A törvény XXVIII. fejezete (759-788. §) a házassági szerződéseket szabályozta. Fiatalkorú menyasszony vagy feleség csak apai illetve gyámi hozzájárulással, valamint bírósági igazolással köthetett ilyen szerződést. Miraz lehetett bármilyen érték, amelyet a feleség hozott magával, beleértve az örökségét is (760-763. §). Minden, ami ingóság volt (ruházat, felszerelés, vagy akár a férjtől kapott ajándék is), az aszszonyé maradt, azokkal a férj nem rendelkezhetett felesége beleegyezése nélkül. A nő is korlátozva volt, mivel férje engedélye nélkül nem adhatta őket el (768. §).

Ha a házasságkötésnél nem rendelkeztek a vagyoni kérdésekről, akkor mindkét fél a saját vagyonának tulajdonosa maradt. Ha az asszony ezt kifejezetten nem ellenezte, akkor úgy tekintették, hogy ő a férjére mint képviselőjére bízta a vagyonkezelést. Bizonyos esetekben (ha a vagyon veszélybe került vagy attól lehetett tartani, hogy azt a férj eltékozolja) a feleség kérhette, hogy a férjétől vonják meg a vagyonkezelési jogot. Ugyanígy a férj is kérelmezhette, hogy feleségét nyilvánítsák tékozlónak, amennyiben a háztartást pazarló módon vezette (73. §).

A szerb nők alárendeltségét vélik felfedezni egyes kutatók abban is, hogy a szerb Ptk. nem vette át az Optk.-ból azt a rendelkezést sem, amely szerint a házasságkötés létrehozza a családot, amelynek célja az utódnemzés és az, hogy a házastársak kölcsönösen támogassák egymást. A szerb törvényben nincs szó a kölcsönös támogatásról, tehát a férfi mentes ez alól. Valójában a szerb feleség jogai és kötelezettségei a shari'a jogban meghonosodott szerepkört idézik fel: a nő a házon belüli munkák, a gyermeknevelés „felelőse,” amíg a férj köteles eltartani a családot. ${ }^{72}$ Ebben pedig látható a hasonlóság a török és az albán családi jogszabályokkal.

A nők számára a legmegalázóbb a 920. § volt, amely rögzítette, hogy saját vagyonukkal nem rendelkezhetnek „a gyengeelméjüek, a bírósági határozattal tékozlóknak nyilvánított személyek, a semmirekellők, az eladósodottak, a csődbe jutottak és a férjes asszonyok".

A szerb Ptk.-ban lefektetett rendelkezések a nők cselekvőképességéröl, vagyoni és öröklési jogairól, feladatairól és társadalmi szerepéről, a házközösséggel kapcsolatos szokásjogon alapultak. Ennek a tradicionális rendnek a továbbélése a kodifikált jogban hosszú időre meghatározta a nők helyzetét a balkáni társadalmakban.

A szerb nőkhöz képest a horvát, szlovén vagy vajdasági nők sokkal szélesebb jogosítványokkal rendelkeztek. Ök ebben az időben már tanítónői, tisztviselői, müvészi munkákat végezhettek.

72 Nagy szégyennek számított, ha a saját házában nem volt képes eltartani a családját, az apósának vagyonára vagy házközösségébe került. Az ilyen férfiakat domazet-nek nevezték (a zet a vő, a doma pedig a ház, otthon), ami családnevekben is megöröklődött. 


\section{A nők társadalmi helyzete a 20. század első felében}

Az Oszmán Birodalom részét képező Szerbiában nem jött létre arisztokrácia. A polgári törvénykönyv megalkotásának idején a lakosság nagyon kis rétege (alig hat százalék) tudott írni-olvasni. Az oktatási szervezet fejletlensége miatt az állami apparátusban dolgozók és a jómódú polgárok (zömében kereskedők) a 19. század közepétől külföldre (gyakran Magyarországra) küldték gyermekeiket tanulni. Koszovó, Montenegró és a mai Észak-Macedónia területén még rosszabb volt a helyzet, de Bosznia-Hercegovinában is csak kevéssel volt jobb.

Országos szinten az 1921. január 31-i adatok szerint írni-olvasni a férfi lakosság $57,1 \%$-a, a nők közül pedig 38,7\% tudott. A szlovén, horvát, dalmát és vajdasági lakosság jóval az átlag fölött teljesített. Az 1931. évi népszámlálás adatai szerint a tíz évnél idősebb korosztályt illetően a Jugoszláv Királyságban a lakosság majdnem fele (48,5\%) írástudatlan volt, Szerbiában ez az arány a lakosság 55,09\%-a (ebből a férfiak 30,86\%-a és a nők 77,8\%-a) volt. Az összképen Belgrád valamelyest javított, ahol a lakosság mindössze 10,93\%-a nem tudott írni és olvasni, viszont a nők 71,2\%-a ott is analfabéta maradt. Koszovóban a lakosság 84,23\%-a (a nők 93,86\%-a), Szandzsákon a 78,65\%-a (a nők 92,33\%-a) volt írástudatlan. ${ }^{73}$ A Vajdaságban (amely évszázadokon keresztül Magyarországhoz tartozott) a helyzet egészen más volt: 1931-ben a nők csupán 23,6\%-a nem tudott írni-olvasni. ${ }^{74} \mathrm{Ez}$ is bizonyítja, mekkora volt a fejlettségbeli különbség az Oszmán Birodalom keretében élő szerb lakosság és a magyarországi szerbek között. A Szerb-Horvát-Szlovén Királyság (1929-tól Jugoszláv Királyság) valójában különböző gazdasági, társadalmi és kulturális fejlettségű tartományok keveréke volt, amivel együtt járt a jogi partikularizmus. Szlovéniában és Dalmáciában az osztrák, Horvátországban, Szlavóniában és Vajdaságban a magyar jog volt érvényes, az ország többi részén a szerb, illetve Bosznia-Hercegovinában, Koszovóban és Macedóniában zömében élő muszlim lakosságra (a mai bosnyákok, albánok és romák) nézve a shari'a jog.

A szerb társadalom elmaradottsága elősegítette a patriarchális rend megmaradását a 20. század első felében is. Ekkor még megkülönböztették a férfi és női munkákat. Az előbbiekhez tartozott a szántás, vetés, aratás, kapálás, kaszálás, favágás, amíg minden házimunka végzése a nők feladata volt. Az udvar takarítása a lányok munkája volt, mert az udvar tisztasága az utcáról is látszott, és ez árulkodott a leány szorgalmáról. A lány 14 éves korában kezdett szépen öltözködni, tánceseményeken részt venni, és a családja megkezdte a hozomány készítését. Ettől a kortól kezdve már nem járhatott egyedül a mezőre, nem hagyhatta el kíséret nélkül az otthonát, senkivel sem beszélhetett kísérő jelenléte nélkül. A fiútestvére, akár öccse is, utasíthatta, parancsolhatott neki. ${ }^{75}$ Ahhoz, hogy minél „jobb” házasságot köthessen, az kellett, hogy felfigyeljenek rá, ezért eljárt a falusi vásárokra, mint a közösségen belüli

\footnotetext{
${ }^{73}$ Bondžıć, Dragomir: Opismenjavanje u Jugoslaviji i Srbiji u periodu 1945-1950: nasleđe, ciljevi, tok, rezultati i nedostaci. Andragoške studije. Institut za pedagogiju i andragogiju, Beograd, 2010, 92.

${ }^{74}$ Stojanović Jovanović, Biljana-Jovanović, Stevan: Sociomedicinski aspekti života žena u Srbiji tokom XX veka. Istorija medicine, 2015, 37. http://www.podaci.net/_z1/9108666/Z-gradan03v0000.html (2020. 08. 23.) (doi: 10.5937/pomc12-8613)

75 Stojanović Jovanović-Jovanović: i. m., 37.
} 
legnagyobb társadalmi eseményekre. Ezeken a legszebb ruhákat viselte, és arany dukátokkal ékesítette magát, amelyet a család akár bérbe is vehetett. A házasságkötést a felek vagyoni helyzete befolyásolta. A kérővel a lány édesapja állapodott meg, és ekkor egyeztek meg a miraz értékéről is.

A nők helyzetét befolyásolták a nemre vonatkozó demográfiai adatok is. 1903-ban Szerbiában 1000 férfira csak 752 nő jutott, Belgrádban pedig 731. Igaz, a falvakban a helyzet kedvezőbb volt, mint a városokban, ott 981 nő jutott 1000 férfira. ${ }^{76}$ Ezzel szemben kontinensünk más részeiben a nők voltak többségben a férfiakkal szemben. ${ }^{77}$ A szerbiai állapot annak tudható be, hogy a nők átlagban tíz évvel kevesebbet éltek, mint a férfiak. 1903-ban a városi lakosság körében a férfiak átlagéletkora 50,93 év volt (a falvakban 49,69), a nőké pedig mindössze 40,66 (a falvakban $41,74)$. Különösen aggasztóknak tủnnek az elvált nők statisztikai adatai: az elvált férfiak átlagban 49,71, a nők pedig mindössze 35,22 évig éltek. Ez kétségtelenül arra utal, hogy az egyedülálló nők megélhetése sokkal nehezebb volt, mint a férfiaké, különösen a városokban. A statisztikákat böngészve észlelhető, hogy nagyobb volt a férfiak halandósága a gyermekkorban (100 fiúra 86 leánygyermek) és a pubertáskorban (100 nőtlen férfira 93,61 hajadon leány). A házasságban lévők esetében 100 elhunyt felnőtt férfira 116 elhunyt feleség jutott.

A balkáni háborúk (1912-1913) és az első világháború változást hoztak a nők életében, mivel a férfiak zöme hadba vonult, közülük sokan elestek. Emellett a férfiak nagyobb számban vándoroltak ki Amerikába. Ezek a tények jelentős „férfihiányt” eredményeztek, így a leánygyermekek szülei akár egy birtokot is kénytelenek voltak eladni a miraz biztosítása érdekében. Egyes szerzők beszámolnak arról, hogy egy „idősebb” lány (21 éves, vagyis lassan már „öregnek” minősülő, mivel általában tizenöt évesen házasodtak) férjhez ment egy 11 éves kisfiúhoz, természetesen nagy hozomány kíséretében. ${ }^{78} \mathrm{~A}$ két világháború között ismét elterjedt a leányrablás, aminek az oka az eljegyzés és a lakodalom költségeinek elkerülése volt, mert az elrabolt leány édesapjának nem kellett esküvőt szerveznie. ${ }^{79} \mathrm{~A}$ vőlegények hiánya miatt a nők elvégezték a férfimunkákat is, beleértve a szántást, az adó befizetését, az üzletkötést, illetve „a tisztviselők lefizetését”.

A második világháborúban ismét nagyszámú férfiáldozat volt, így a nők közül sokan megözvegyültek. Már nemcsak háziasszonyok és anyák voltak, hanem minden „férfimunka” is rájuk hárult. A mostoha életkörülmények, a nehéz fizikai munkának számító mezőgazdasági munka, az állattenyésztés igen kimerítette őket. Ilyen körülmények mellett természetesen bármilyen oktatás elképzelhetetlen volt. Ezért Szerbiában a falusi lakosság körében, föleg a nőknél nagyon magas volt az analfabetizmus. Még az 1948-as népszámlálás adatai is arra utalnak, hogy Szerbia lakossága nem tudott felzárkózni az országos szinthez. A szocialista Jugoszláviában 25,4\%-a

\footnotetext{
${ }^{76}$ Statistički godišnjak Kraljevine Srbije za 1903. godinu. Beograd, 1906, 43.

77 A 20. század elején Németországban 1032 nő jutott 1000 férfira, Ausztriában 1035, Angliában 1063, Norvégiában pedig 1060. JoKsıMovıć, Hranislav: Zdravlje naših ženskinja. Narodno zdravlje, 1911/4, 64.; STOJANOVIĆ JoVANOVIĆ-JOVANOVIĆ: i. m., 36.

78 Isıć, Momčilo: Žena i dete u Srbiji između dva svetska rata, 4, In: Perović, Latinka (szerk.): Srbija u modernizacijskim procesima 19. i 20. veka. Žene i deca, Beograd 2006, 142-168.

${ }^{79}$ Isıć: i. m.
} 
volt az írástudatlanok aránya. Szerbia polgárainak bő egynegyede (26,7\%-a), Bosznia-Hercegovinában pedig a lakosság 44,8\%-a analfabéta volt. Ugyanakkor Szlovéniában ez a szám mindössze 2,4\%-a volt (szinte kizárólag idősek).80

A balkáni lakosság zöme a falvakban élt, ahol semmi nem ösztönözte őket a tanulásra. Biljana Stojanović Jovanović és Stevan Jovanović a szerb falusi lakosság higiéniai-egészségügyi szokásairól írt tanulmányukban megjegyzik, hogy a falusiak többsége csak nyáron fürdött, az idősebbek gyakran akkor is mindössze egyszer, „mielőtt mentek áldozni”. ${ }^{81}$ Régi feljegyzésekre hivatkozva azt is megemlítik, hogy a házi szappan helyet sokszor hamut használtak, emellett hozzáteszik, hogy a nők hetente egyszer fésülték meg hajukat. A férfi és a női jogokat erősen megkülönböztették: a nőknek tilos volt az éjjeli munka, nem dolgozhattak a bányákban, a várandós hölgyeket hat héttel a szülés előtt és után felmentették a munkavégzés alól.

Mindebből érthetővé válik, hogy miért lettek számukra a horvát, szlovén vagy vajdasági nők a követendő példák. Azonban több mint nyolc évtizedes együttélésnek kellett eltelni ahhoz, hogy a szerb nőkben is megerősödjön az a tudat, hogy a nők és a férfiak egyenrangúak. ${ }^{82} \mathrm{~A}$ férfiak azonban gátolni próbálták az ilyen jellegü változásokat. Amikor a Szerb-Horvát-Szlovén Népi Női Szövetség 1925. május 18-án benyújtotta a női öröklés egyenjogúságáról szóló indítványát, a belgrádi szkupstinában a szerb képviselők mellett a más nemzetiségủ honatyák egy része is elutasította azt. ${ }^{83}$

A délszlávok közül az első női szervezetek Horvátországban alakultak meg még az Osztrák-Magyar Monarchia keretében. A választójog elnyerése mellett az egzisztenciális bizonytalanság megszüntetése volt e mozgalmak célja. ${ }^{84} \mathrm{~A}$ szervezetek tevékenysége karitatív, oktatási jellegű volt, legfőképpen kulturális és művészeti programok szervezésére irányult. Petrinjaban 1908-ban, majd Zágrábban 1913-ban megalakult a Népi Kézműves és Varró Egylet, amely a falusi asszonyok gazdasági helyzetének javítását célozta, hiszen azok kézimunkáik eladásával saját bevételhez juthattak. A két világháború közötti időszakban a horvát és szlovén nők nagyobb számban vállaltak közéleti szerepet. Ekkor már a rosszul fizetett gyári munkák, a házimunkák illetve a mezőgazdasági munkák helyett intellektuális tevékenységet folytattak: festőművészek, írónők, tanítónők, óvónők, ápolónők lettek, és csakhamar saját női egyleteket is létrehoztak.

A női jogokért síkraszálló politikai egyesületekről a délszláv térségben 1926-töl lehet beszélni, amikor megalakult a Női Mozgalom nevű szervezet. Ez a szervezet túllépett a meglévő, zömében humanitárius munkával foglalkozó női egyleteken. A második világháború előtt a nők részvétele a politikai, gazdasági és kulturális életben

80 StOJANOVIĆ JoVANOVIĆ-JOVANOVIĆ: i. m., 36.

81 STOJANOVIĆ JoVANOVIĆ-JoVANOVIĆ: i. m., 37.

82 Perić, Živojin: Žena u Srpskom građanskom zakoniku. Arhiv za pravne i društvene nauke, 1928, 68.; AvRAMović: i. m., 33.

${ }^{83}$ PANTElıć, Ivana: Neki aspekti položaja žena u Kraljevini Jugoslaviji. Knjiženstvo, 2011/1, http://www.knjizenstvo.rs/sr-lat/casopisi/2011/zenska-knjizevnost-i-kultura/neki-aspekti-polozaja-zena-u-kraljevini-jugoslaviji\#gsc.tab=0 (2020. 09. 20.).

84 ČaldAROvić Peić, Dubravka: Ženska posla' između obitelji i profesije (Profesionalna djelatnost žena u Hrvatskoj 1918-1941 u društveno-ekonomskom kontekstu). Otivum, 1999-2000, 66-74. God. 29, 3, $1997,492$. 
csak szimbolikus volt. A női jogok élharcosa az 1931 novemberében létrejött „Jugoszláv nő" (Jugoslovenska žena) folyóirat lett.

\section{A nök helyzete a szocialista Jugoszláviában}

A délszláv állam keletkezésével megindult az emancipáció, amely javított a nők társadalmi helyzetén. Megkapták az oktatáshoz és a munkához való jogot, de ez több feladatot is jelentett számukra. A házimunkán és a gyermeknevelésen túl munkát vállaltak, amelyért a férfiaknál alacsonyabb fizetést kaptak, és az előrelépés is sokkal nehezebb volt számukra. A 20. század húszas-harmincas éveiben már Szerbiában is részt vehettek az oktatásban. Azonban egy állami tisztviselői állásra (orvosi, tanári, mérnöki stb.) való kinevezést csak miniszteri ukázzal, a katonai szolgálat teljesítése után lehetett pályázni. Mivel a nők nem voltak katonakötelesek, automatikusan kizárták őket ezekből a hivatásokból. Az orvosi végzettségü hölgyek legfeljebb ápolónők, a bölcsész képesítésűek maximum tanítónők, a mérnöki végzettségűek pedig tervrajzolók lehettek.

A szocialista Jugoszlávia 1946. évi alkotmánya proklamálta a férfiak és a nők egyenjogúságát (24. §). Az 1946 évi Házassági Törvény (Osnovni zakon o braku) hatályon kívül helyezte a katolikus, pravoszláv és muszlim vallási törvényeket, illetve a Jugoszláv királyságbeli egyéb jogszabályokat. ${ }^{85}$ Ettöl kezdve a házassági és családjog az egyházi fennhatóság helyett az állami joghatóság alá került. Az egyenjogúság jegyében a házassági törvény a nőknek biztosította a családnév megválasztásának jogát, elöírta, hogy a szülői felügyeleti jog gyakorlása a szülőket együttesen illeti stb. Az öröklésröl szóló 1955. évi törvény rendelkezett a férfiak és nők azonos öröklési képességéről, függetlenül attól, hogy az örökös törvényes házasságból született-e vagy házasságon kívül. ${ }^{86}$

A gyakorlatban azonban még sokáig megmaradt a nők helyzetének patriarchális jellege: a néphagyományból megöröklődött szokások tovább éltek. Jóllehet a gyermekek számára kötelező volt az általános iskolai oktatás, mégis Szerbiában, Montenegróban, Koszovóban és Macedóniában a szülők (leginkább a hegyvidékiek) gyakran nem küldték gyermekeiket (föként a leánygyermekeket) iskolába. ${ }^{87}$ 1952-ben Jugoszláviában bevezették a nyolcosztályos kötelező oktatást. Az egy évvel későbbi adatok szerint az ország keleti részében a nők több mint fele vagy írástudatlan volt, vagy legfeljebb három osztályt végzett. Ha ehhez a kategóriához hozzáadjuk az alsó négy osztályt végzetteket, akkor a nők $92 \%$-a ezekbe sorolható volt. A helyzet csak lassan javult. Az 1961/62. tanévben Szerbiában a leánygyermekek 46,6 \% látogatta az iskolákat, az 1970-es-1980-as években pedig már szinte mindenki részt vett a kötelező általános iskolás oktatásban. Ez tette lehetővé a nők számára a továbbkép-

${ }^{85}$ Osnovni zakon o braku, Službeni list FNRJ, 1946. VI. 9., 6. §.

${ }^{86}$ DrAŠKıĆ, Marija-Popović-OBRadović, Olga: Pravni položaj žene prema Srpskom građanskom zakoniku (1844-1946). In: Perović (1994): i. m., 19-21.; Božınović: i. m., 159.

${ }^{87}$ Az 1882. évi szerb törvény hatéves kötelező általános oktatást írt elő, az 1898. évi népi iskolákról szóló törvény pedig kötelező négyéves általános oktatást, mindkét nemű gyermekek számára. 
zést, a jobban fizetett munkahelyeken való elhelyezkedést és a társadalmi felemelkedést. Ekkor nyílt meg az út az egyenjogúság felé.

\section{Zárógondolat}

A 19. századi gazdasági változások, a modernizáció, valamint az emancipáció alig érintették a balkáni nők jogi és társadalmi helyzetét. Főként a szerb nőkét nem, akiknek jogi státusát az 1844. évi szerb Ptk. rögzítette. A férjezett szerb nők cselekvőképességgel nem rendelkeztek (úgy, mint a kiskorúak, szellemi fogyatékosak vagy vagyontékozlók), javadalmaikat férjeik kezelték. Nem lehettek végrendeleti tanúk vagy gondnokok, férjük hozzájárulása nélkül ajándékot sem fogadhattak el. A szülöi jogokat is a férj gyakorolta, a hagyatékból pedig a nők csak akkor részesülhettek, ha tizenkettedik fokig nem volt férfi örökös (ami a patriarchális társadalmakban igen kivételes esetben fordult csak elő). A jogszabályok alapján özvegyként maradhattak ugyan a birtok haszonélvezői, de a gyakorlatban nem volt ritka, hogy elküldték őket (gyermekeikkel együtt) korábbi férjük házából. Ez utóbbi megoldás teljesen ellentétes volt más balkáni népek gyakorlatával, hiszen ott nem történhetett meg, hogy a nőt rokonai kizárják férje vagyonából, földönfutóvá téve őt. Még a shari'a jog is biztosította a muszlim nőknek a mahrösszeget (a házassági szerződés megkötésénél férje által megígért pénzösszeg vagy érték) és a hozományt (miraz). Igaz, az öröklési jog szabályai szerint a nők csak feleannyit örököltek, mint a férfiak, de ez is sokkal kedvezőbb anyagi helyzetbe hozta őket, mint amilyet a törvény a szerb nőknek biztosított. Habár már a 20. század elején megkezdődött a nők emancipációja, valójában csak a 20 . század végén harcolták ki az egyenjogúságot. 